Table 2. Stability constants of COBalt(II) BRomide COMPLexes VALID FOR $20^{\circ}$ AND $0.691 \mathrm{M}$ PERCHLORIC ACID

$\beta_{1}=0.74 \pm 0 \cdot 1 \mathrm{M}^{-1} \quad \beta_{2}=0.38 \pm 0 \cdot 1 \mathrm{M}^{-2}$

introduced by Fronaeus, ${ }^{1}$ with the resin, Amberlite IR-120 (30-80 mesh), in the hydrogen form. The experimental procedure, which involved the use of ${ }^{60} \mathrm{Co}$ as a tracer, was generally similar to that described in a previous communication. ${ }^{2}$

The distribution ratios measured at $20^{\circ} \mathrm{C}$ and the functions necessary for the derivation of stability constants are given in Table 1 . The notation and method of calculation have been described by Morris and Short. ${ }^{2}$. The results obtained for the stability constants, $\beta_{j}=\left[\mathrm{CoBr}^{(2-j)+}\right] /\left[\mathrm{Co}^{2+}\right]\left[\mathrm{Br}^{-}\right]^{j}$, are presented in Table 2. Our study provides no evidence for the existence of complexes with $j>2$ in solution in the range $\left[\mathrm{Br}^{-}\right] \leqslant 0.58 \mathrm{M}$, though anionic species are known to be formed at higher bromide concentrations. ${ }^{3}$

In the case of cobalt(II) it appears that chloride complexes are stronger than corresponding bromide complexes.

\title{
REFERENCES
}

1. S. Fronaeus, Svensk Kem. Tidskr. 65, 19 (1953).

2. D. F. C. Morris and E. L. ShORT, Electrochim. Acta 7, 385 (1962).

3. R. H. Herber and J. W. Irvine, J. Amer. Chem, Soc. 76, 987 (1954).

Electrochimica Acta, 1965, Vol. 10. pp. 474 to 475. Pergamon Press Ltd. Printed in Northern Ireland

\section{ON THE ELECTROCHEMICAL BEHAVIOUR OF MOLTEN NITRITES*}

\author{
A. J. Calandra and A. J. Arvía \\ Instituto Superior de Investigaciones, Facultad de Química y Farmacia and \\ División Ingenieria Química, Facultad de Ciencias Físicomatemáticas, \\ Universidad Nacional de La Plata, La Plata, Argentina
}

THE results obtained for the electrolysis of molten nitrates ${ }^{1-3}$ encouraged us to investigate the electrochemical behaviour of molten nitrites, as the processes involved might be related to those previously described for the molten nitrates. This preliminary report deals with the results obtained during electrolysis of pure molten sodium nitrite at $\mathrm{ca} 290^{\circ} \mathrm{C}$.

Molten salt was electrolysed in a Pyrex glass container provided with a platinum anode, its potential being measured against a silver/silver-ion $\left(\mathrm{Ag}^{-+}, 2 \times 10^{-3}\right.$ mole fraction) reference electrode in the eutectic $\mathrm{KNO}_{3}-\mathrm{NaNO}_{3}(1: 1)$, placed in a special container with a Luggin-Haber capillary tip.

The electrolysis was performed with the electrodes placed in different compartments to separate the products yielded by the cathodic and anodic reactions and to maintain a constant gas composition of the gaseous mixture in the anodic section of the cell. The current/voltage curves were measured in the usual way. The anodic current density was varied between $1.5 \times 10^{-5}$ to $2.4 \times 10^{-1} \mathrm{~A} / \mathrm{cm}^{2}$.

* Manuscript received 31 July 1964. 
The anodic reaction is represented by

$$
\mathrm{NO}_{2}^{-}=\mathrm{NO}_{2}+\mathrm{e}
$$

$\mathrm{NO}_{2}$ was identified as the product yielded by the anodic reaction.

When the electrolysis current was switched off, a reversible cell was formed between the working electrodes of the cell. The potential of the anode measure against the reference electrode was $-0.300 \mathrm{~V}$ at $306^{\circ} \mathrm{C}$. This formation of a reversible electrode at the platinum anode has also been demonstrated by measuring its potential against a sodium/sodium-ion reversible electrode in pure molten sodium nitrate. The emI of the $\mathrm{Na} / \mathrm{NaNO}_{2} / \mathrm{NO}_{2}$, Pt cell is $2.72 \mathrm{~V}$ at $306^{\circ} \mathrm{C}$. The potential of the residual cell formed after the interruption of the electrolysis current was independent of the current intensity that previously flowed through the cell and showed typical reversible behaviour. Considering the reported value for the standard reversible potential of nitrate electrode referred to the standard sodium electrode, ${ }^{2}$ the difference between the standard reversible potential of nitrate and nitrite $\mathrm{NO}_{2}$ electrodes at $306^{\circ} \mathrm{C}$ is $0.825 \mathrm{~V}$.

The current/voltage curves indicate the existence of an overpotential. The Tafel slope is $109=5 \mathrm{mV}$ at $277^{\circ} \mathrm{C}$. This value is quite close to $2 \cdot 303 R T / F$, and it indicates that the transfer coefficient $\alpha$ is unity. The Tafel slope was also determined by measuring the rate of decay of the anodic overpotential at current interruption. The overpotential decayed logarithmically with time and the average slope obtained from overpotential $v s \log t$ plots was $109 \pm 5 \mathrm{mV}$, in good agreement with the figure resulting from current/voltage curves as mentioned above.

A detailed discussion of the foregoing effects will be published shortly.

Acknowledgement-This work was supported in part with funds from the Consejo Nacional de Investigaciones Cientificas y Técnicas of Argentina.

\section{REFERENCES}

1. W. E. Triaca and A. J. Arvía, Electrochim. Acta 9, 919 (1964).

2. A. J. Arvía, A. J. Calandra and W. E. Triaca, Electrochim. Acta 9, 1417 (1964).

3. W. E. Triaca and A. J. Arvía, Electrochim. Acta, 10, 409 (1965). 